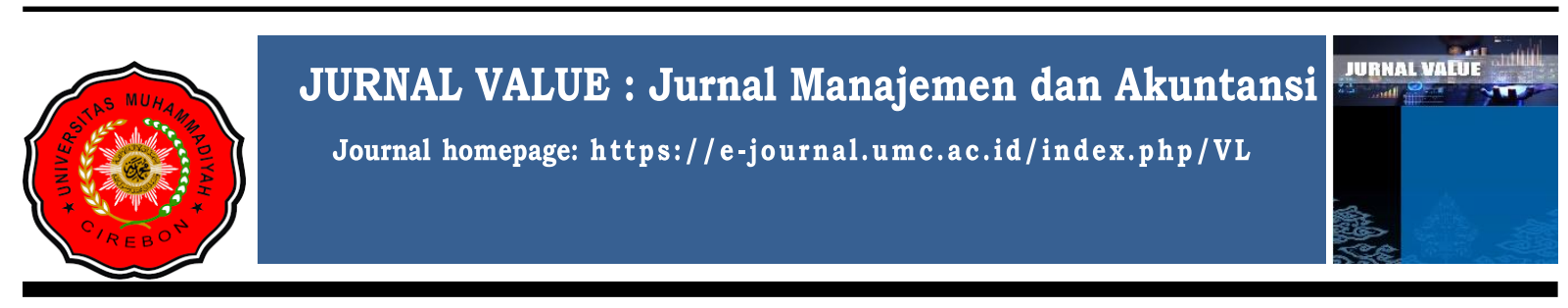

\title{
ANALISIS DAN PENYUSUNAN PANDUAN JENJANG KARIR PEGAWAI KELOMPOK STAF NON-DOSEN AKADEMI TEKNIK SOROAKO
}

\author{
Jasman $^{1 *}$ \\ Didit Yantony ${ }^{2}$ \\ ${ }^{1}$ Program Studi Perawatan dan Perbaikan Mesin, Akademi Teknik Soroako (ATS) Sorowako \\ Email: jasman@ats-sorowako.ac.id \\ ${ }^{2}$ Program Studi Perawatan dan Perbaikan Mesin, Akademi Teknik Soroako (ATS) Sorowako \\ Email: didit.yantony@ats-sorowako.ac.id \\ *Correspondent Author Email: jasmansoraja@gmail.com
}

Diterima : 24 November 2021 Direvisi : 5 Desember 2021 Dipublikasikan : 31 Desember 2021

\begin{abstract}
Abstrak
Pegawai Staf Non-Dosen Akademi Teknik Soroako (ATS) saat ini hanya memiliki dua tingkatan jenjang karir dan tidak memiliki ruang seperti halnya pada jalur karir Dosen. Hal ini menimbulkan kendala pada pengembagan karir jangka panjang dan menurunkan kinerja pegawai. Penelitian ini bertujuan menganalisis dan menyusun panduan jenjang karir pegawai Staf Non-Dosen ATS. Metode penelitian menggunakan pendekatan deskriptif. Data primer diperoleh dengan cara analisis dokumen kepegawaian dan wawancara terhadap 13 orang pegawai dan semua dijadikan sebagai sampel. Hasil analisis menunjukkan bahwa pegawai Staf Non-Dosen ATS terdiri dari Officer Administrasi dan Pengawas Produksi merupakan manajemen lini pertama yang memiliki 2 level jenjang karir dan tidak memiliki ruang. Sedangkan karir Dosen memiliki 4 level dan masing-masing level memiliki 4 ruang. Perbedaan tersebut merupakan kesenjangan dalam pengelolaan karir di ATS yang berakibat pada tingginya upaya pegawai Staf Non-Dosen beralih ke jalur karir Dosen dan berpotensi menurunnya kinerja pegawai. Untuk menghilangkan kesenjangan, maka penelitian ini merumuskan jenjang karir baru terdiri dari 3 level dan masing-masing level memiliki 4 ruang. Persyaratan profesional setiap ruang terdiri dari kompetensi tehnis, kompetensi manajerial dan kepemimpinan, dan kompetensi K3. Persyaratan operasional terdiri dari prestasi kehadiran, disiplin, dan penilaian kinerja. Hasil penelitian dapat digunakan sebagai acuan pengelolaan karir pegawai Staf Non-Dosen ATS.
\end{abstract}

Kata Kunci: Jenjang karir, Staf Non-Dosen, Profesional, Operasional.

\section{PENDAHULUAN}

Yayasan Pendidikan Soroako (YPS) adalah badan hukum yang didirikan oleh perusahaan nikel PT Vale Indonesia, Tbk. di Sorowako Sulawesi Selatan untuk memayungi sekolah-sekolah yang berada dalam pembiayaannya melalui dana CSR (corporate social responsibility), mulai dari taman kanakkanak hingga perguruan tinggi, yang salah satunya adalah Akademi Teknik Soroako (ATS). ATS adalah perguruan tinggi vokasi rumpun keilmuan teknik pemesinan dengan program studi Perawatan dan Perbaikan Mesin. Sebagai perguruan tinggi vokasi, maka aktivitas praktikum mahasiswa dan bahkan terjun langsung pada bidang produksi menjadi lebih dominan dibandingkan dengan pembelajaran teori di kelas. Keadaan ini mempengaruhi komposisi pegawai yang terdiri dari pegawai dengan aktivitas bidang kependidikan yang mengacu pada pedoman tridharma perguruan tinggi yang ditetapkan oleh Kemendikbud-Ristek dan pegawai aktivitas non-kependidikan seperti pelaksanaan aktivitas produksi. Pada Buku Peraturan Kepegawaian YPS telah mengelompokkan pegawai kependidikan dan nonkependidikan ATS berdasarkan macam dan variasi benefit yang diterimanya terdiri dari pegawai kelompok Staf dan Non-Staf. Pegawai kelompok Staf terdiri dari pegawai yang berprofesi di bidang akademik seperti dosen dan instruktur, disebut kelompok Staf Dosen dan pegawai kelompok Staf yang 
berprofesi di luar bidang akademik seperti bidang produksi dan administrasi, disebut kelompok Staf Non-Dosen.

Kelompok Staf Non-Dosen yang merupakan obyek penelitian ini menjalankan tanggung jawab sebagai pengawas pada bidang administrasi institusi yang disebut Officer Administrasi dan pengawas pada divisi produksi disebut Pengawas. Jenjang karir yang saat ini berlaku di ATS terhadap pegawai kelompok Staf Non-Dosen hanya terdiri dari dua tingkatan saja, yaitu Level I dan Level II. Masingmasing Level berdiri tunggal dan tidak memiliki Ruang seperti halnya pada jalur karir kelompok dosen. Keterbatasan tingkatan karir pegawai kelompok Staf Non-Dosen tersebut menyebabkan seorang pegawai hanya membutuhkan waktu rata-rata antara 4 sampai dengan 8 tahun untuk mencapai tingkatan teratas. Pegawai Staf Non-Dosen yang telah mencapai jenjang paling atas tidak memiliki lagi jalur pengembangan karir selain berpindah ke jalur karir dosen jika mendapatkan kesempatan. Dengan keterbatasan tingkatan jenjang karir pegawai kelompok Staf Non-Dosen tersebut menjadi kendala penting dalam perencanaan pengembagan sumber daya manusia secara jangka panjang dan berpotensi pula dalam menurunkan kinerja pegawai.

Berdasarkan uraian di atas yang bersumber dari tinjauan pada dokumen kepegawaian dan hasil wawancara awal dengan pegawai personalia ATS terlihat bahwa pengelolaan karir pegawai kelompok Staf Non-Dosen di Akademi Teknik Soroako masih belum optimal sebagai sarana untuk mengembangkan sumber daya manusia institusi, khususnya ATS sebagai perguruan tinggi vokasi yang erat kaitannya dengan aktivitas produksi. Demikian pula dengan adanya pernyataan pegawai kelompok Staf Non-Dosen melalui wawancara awal bahwa banyak upaya pegawai untuk beralih jalur karir ke kelompok Staf Dosen. Fakta-fakta di atas merupakan hal menarik untuk dilakukan analisis dan dilanjutkan dengan penyusunan jenjang karir pegawai kelompok Staf Non-Dosen di Akademi Teknik Soroako. Selain merupakan amanah peraturan kepegawaian yayasan, juga dengan adanya jenjang karir yang komprehensif merupakan kesempatan bagi institusi untuk mengembangkan karir pegawainya dan dapat menjadi pendorong untuk mencapai prestasi kerja yang diharapkan oleh institusi maupun pegawai Staf Non-Dosen ATS.

\section{KAJIAN PUSTAKA}

Menurut Rivai \& Sagala (2009:267) perencanaan karir merupakan cara untuk memenuhi kebutuhan internal karyawan. Dengan perencanaan karir para karyawan dapat menetapkan tujuan karirnya yang akan mendorongnya untuk meraih jenjang pendidikan lebih lanjut, pelatihan, dan kegiatan pengembangan lainnya. Pengembangan karir haruslah mempertimbangkan keinginan karyawan. Menurut Brown \& Lent (2013:11) menjelaskan bahwa pilihan karir dapat dilihat sebagai proses memilih dan memasuki jalur karir tertentu, sedangkan pengembangan karir mengacu pada pengalaman seseorang sebelum, selama, dan (terutama) setelah pilihan karir. Karir terdiri dari semua pekerjaan yang ada selama seseorang bekerja, atau dapat pula dikatakan bahwa karir adalah seluruh jabatan yang diduduki seseorang dalam kehidupan kerjanya.

Konsep-konsep dasar perencanaan karir yaitu: a) karir adalah model posisi kerja yang dijabat selama siklus kehidupan pekerjaan seseorang, b) jenjang karir adalah model posisi pekerjaan berurutan yang membentuk karir seseorang, c) tujuan karir adalah posisi mendatang yang diupayakan pencapaiannya oleh seseorang sebagai bagian karirnya yang berperan sebagai benchmark sepanjang jenjang karir seseorang, d) perencanaan karir adalah proses untuk seseorang menyeleksi tujuan karir dan jenjang karir menuju tujuan-tujuan tersebut, dan e) pengembangan karir adalah peningkatan pribadi yang dilakukan oleh seseorang dalam mencapai rencana karir pribadinya. (Rivai \& Sagala, 2009:266). Perencanaan karir membantu menyiapkan pekerjaan yang lebih penting serta pelaksanaan rencana kegiatan yang telah ditentukan. Peran karyawan dalam suatu perusahaan sangat penting, maka kegiatan pengembangan karier karyawan merupakan hal penting pula dalam upaya peningkatan prestasi kerja karyawan, misalnya melalui pendidikan karier, informasi karier, dan bimbingan karier. (Rivai \& Sagala, 2009:270). Perencanaan dan pengembangan karier harus dapat memberikan kepastian kepada karyawan lebih transparan dan terjamin serta dapat menumbuhkan dan mengembangkan semua kemampuan, intelektual, wawasan, motivasi, dan dedikasi karyawan pada posisi pekerjaan yang diemban. (Pio, 2017)

Pada penelitian (Tan, 2008) menyatakan bahwa karir sebagai suatu proses perkembangan seorang individu melalui pengalaman kerja dan jabatan-jabatan yang berbeda dalam satu atau beberapa organisasi dan jenjang karir menyangkut suatu upaya formal yang terencana dan terorganisasi untuk mencapai suatu keseimbangan antara kebutuhan karir seorang individu dengan tuntutan pekerjaan 
dalam suatu organisasi. Konsep jenjang karir telah ada sejak bertahun-tahun yang lalu yang secara historis mengacu pada kemajuan karir di tempat kerja yang dikelola oleh organisasi dan selama beberapa tahun terakhir jalur karir telah menjadi semakin popular didiskusikan dalam kaitannya dengan pengembangan tenaga kerja dan pembangunan ekonomi. (Hedge \& Rineer, 2017). Jenjang karir sebagai kemajuan karir vertikal yang ditentukan perusahaan merupakan sistem terstruktur berdasarkan hirarki pekerjaan yang terdiri dari serangkaian tugas dan tanggung jawab yang kompleks pada suatu area kerja. Kemajuan karir dalam sebuah organisasi akan berlanjut sampai individu meninggalkan perusahaan untuk mendapatkan kesempatan pada karir lain, mencapai usia pensiun, atau diberhentikan dari perusahaan (Society for Human Resources Management, 2015) yang dikutip dalam Hedge \& Rineer (2017).

Penilaian kinerja (performance appraisal) adalah deskripsi sistematis dari kekuatan dan kelemahan seorang karyawan. Sebuah sistem yang melibatkan evaluasi karyawan setahun sekali tanpa adanya upaya berkelanjutan untuk memberikan umpan balik dan pembinaan sehingga kinerja dapat ditingkatkan bukanlah sistem kinerja yang benar. (Aguinis, 2013). Penilaian kinerja adalah komponen penting dari kinerja manajemen, namun itu hanya salah satu bagian saja karena kinerja manajemen lebih dari sekedar pengukuran kinerja. Penilaian kinerja adalah kunci dari fungsi sumber daya manusia yang berkaitan dengan evaluasi karyawan dan penilaian formal secara individual oleh atasan mereka. (Armstrong, 2009:58). Penelitian yang dilakukan oleh Butali \& Njoroge (2018) menyimpulkan bahwa penilaian kinerja menunjukkan pengaruh yang penting terhadap kinerja organisasi. Berdasarkan penelitian tersebut, maka penilaian kinerja terhadap pegawai kelompok Staf Non-Dosen di ATS menjadi salah satu elemen penting sebagai instrumen jenjang karir pegawai.

\section{METODE PENELITIAN}

Pegawai kelompok Staf Non-Dosen secara fungsional adalah pegawai level staf yang berperan sebagai manajemen lini pertama, yaitu Officer Administrasi dan Pengawas pada aktivitas produksi dan administrasi. Jumlah pegawai kelompok Staf Non-Dosen pada bagian administrasi adalah 2 orang dan satu diantaranya memiliki jabatan struktural Kepala Bagian yang membawahi total 9 orang pegawai pelaksana administrasi pendidikan dan produksi. Sedangkan pegawai kelompok Staf Non-Dosen pada divisi produksi adalah 11 orang dan 3 diantaranya memiliki jabatan struktural sebagai Kepala Bagian yang membawahi total 115 orang pegawai pelaksana produksi pada bagian perencanaan produksi, gambar dan disain, fabrikasi, permesinan, dan furnitur. Sampel dalam penelitian ini adalah sampel jenuh, yaitu semua pegawai kelompok Staf Non-Dosen berjumlah 13 orang. Hal ini mengacu pada Sugiono yang dikutip dalam Ismail \& Sudarmadi (2019) bahwa teknik pengambilan sampel jenuh apabila anggota populasi seluruhnya digunakan sebagai sampel.

Penelitian ini menggunakan metode analisis deskriptif yaitu memberikan penjelasan terhadap data yang diperoleh dari hasil pengamatan yang bertujuan memberikan gambaran secara obyektif terhadap obyek yang diteliti. Data primer diperoleh dengan cara analisis dokumen kepegawaian dan wawancara terhadap seluruh sampel. Hasil analisis digunakan sebagai acuan dalam penyusunan panduan jenjang karir pegawai kelompok Staf Non-Dosen. Panduan jenjang karir tersebut diharapkan dapat digunakan oleh ATS sebagai panduan pengelolaan karir pegawai level staf kelompok Non-Dosen di Akademi Teknik Soroako.

\section{HASIL DAN PEMBAHASAN}

Analisis dokumen kepegawaian yang dilakukan dalam penelitian ini adalah fokus pada job description pegawai kelompok Staf Non-Dosen. Analisis terhadap tujuan dan sasaran jabatan untuk seluruh pegawai Staf Non-Dosen ditemukan bahwa pegawai harus memiliki kemampuan memimpin (leadership), mengoordinasi, mengendalikan kegiatan, membina pegawai, implementasi program Keselamatan dan Kesehatan Kerja (K3), dan pemenuhan sasaran mutu pada masing-masing bidang kerja pegawai. Kemampuan tersebut diperoleh melalui pendidikan formal, pelatihan, bimbingan dari atasan masing-masing, dan pengalaman bekerja.

Kemampuan kepemimpinan pada hasil analisis di atas didukung oleh penelitian Kathuria et al. (2010) bahwa penggunaan kepemimpinan yang efektif secara positif terkait dengan kinerja. Demikian pula penelitian oleh Karyono (2021) bahwa gaya kepemimpinan memiliki pengaruh positif terhadap kinerja karyawan. Kemampuan manajerial mengoordinasi, mengendalikan, dan pembinaan pegawai pada hasil analisis di atas didukung oleh penelitian Bhardwaj \& Punia (2013) yang menyatakan bahwa 
penilaian kompetensi manajemen adalah penelitian utama secara global dan kompetensi ini yang membawa individu dan institusi ke tingkat yang lebih tinggi dan didukung pula oleh Wirda et al. (2016) bahwa kompetensi manajerial berpengaruh terhadap kinerja usaha, serta Hanum et al. (2020) bahwa semakin tinggi kompetensi dan pengetahuan manajemen akan semakin kuat pengaruhnya terhadap kinerja karyawan. Namun hal ini berbeda dengan penelitian Junaedi et al. (2019) terhadap kompetensi manajerial kepala sekolah yang tidak berpengaruh terhadap kinerja guru. Perbedaan ini terjadi karena Kelompok Staf Non-Dosen memiliki bawahan para pegawai atau karyawan yang melaksanakan proses produksi dan aktivitas administrasi yang berbeda dengan profesi guru yang dibawahi oleh kepala sekolah. Kemampuan K3 yang harus dimiliki oleh kelompok Staf Non-Dosen pada penelitian ini didukung oleh Wahyuni et al. (2018) yang menyatakan bahwa program K3 mempunyai pengaruh penting dan signifikan terhadap performance karyawan. Demikian pula Harnawan \& Hakim (2020) bahwa program K3 karyawan memiliki pengaruh yang parsial terhadap produktivitas karyawan dan alat pengamanan yang ada di tempat kerja berfungsi dengan baik adalah yang paling berpengaruh terhadap variabel program K3, serta Khotimah (2018) bahwa kinerja karyawan sangat dipengaruhi oleh kompetensi $\mathrm{K} 3$ yang dimilikinya.

Hasil analisis di atas menunjukkan bahwa penguatan kemampuan profesional seperti kepemimpinan, manajemen, dan K3 menjadi elemen pada persyaratan jenjang karir pegawai kelompok Staf Non-Dosen ATS adalah sangat tepat. Untuk mencapai kemampuan kepemimpinan, manajemen, dan K3, maka setiap pegawai kelompok Staf Non-Dosen harus memiliki pengetahuan dengan jenjang pendidikan tertentu sesuai penelitian Tombokan et al. (2017) bahwa pendidikan dan kinerja berpengaruh penting terhadap karir pegawai, penelitian Garnida (2017) bahwa pendidikan berpengaruh terhadap pengembangan karir pegawai. Demikian pula Wulandari (2017) bahwa pendidikan berpengaruh secara penting terhadap prestasi kerja karyawan melalui motivasi kerja dan Budiadnyana et al. (2021) yang menjelaskan bahwa memberikan pengetahuan kepada orang yang tepat dan pada waktu yang tepat sehingga akan membuat keputusan yang tepat dan ini berperan penting dalam meningkatkan kinerja.

Analisis job description kelompok Staf Non-Dosen terhadap tanggung jawab dan tugas utama menunjukkan spesifikasi kemampuan sesuai dengan ruang lingkup pekerjaan yang membutuhkan kemampuan teknikal. Perencana Produksi memiliki spesifikasi kemampuan utama seperti perencanaan dan penjadualan work order, estimasi dan penawaran harga, penentuan material, dan penentuan mesin dan peralatan. Pengawas Permesinan, Fabrikasi, dan Furnitur memiliki spesifikasi kemampuan utama seperti menyusun prosedur kerja standar pada mesin, pembagian pekerjaan kepada karyawan atau operator mesin, sistem dan pengoperasian mesin, proses permesinan atau manufaktur produk work order, pengendalian mutu produk, dan pelaporan hasil produksi. Officer Administrasi memiliki spesifikasi kemampuan utama seperti penyusunan program kerja, mengoordinasi proposal dan penggunaan anggaran, sistem administrasi akademik, sistem administrasi kemahasiswaan, pengelolaan surat-menyurat, kerumahtanggan institusi, pengarsipan, dan administrasi kepegawaian. Penelitian Parta \& Mahayasa (2021) menyatakan bahwa keterampilan kerja sangat berpengaruh terhadap kinerja karyawan dan secara simultan teamwork dan motivasi memberikan pengaruh yang sama. Penelitian Elnaga \& Imran (2013) yang fokus pada pelatihan karyawan untuk menambah nilai kinerja karyawan karena pelatihan memainkan peran penting dalam membangun pengetahuan (knowledge), keterampilan (skills), dan kemampuan (abilities) karyawan untuk melakukan pekerjaan mereka dengan cara yang efektif. Hasil analisis menunjukkan bahwa kompetensi tehnikal bagian dari persyaratan profesional pada jenjang karir pegawai kelompok Staf Non-Dosen.

Analisis terhadap operasional pegawai kelompok Staf Non-Dosen, ditemukan bahwa para pegawai melakukan absensi melalui mesin fingerprint untuk memastikan kehadiran tepat waktu, penerapan disiplin dengan peringatan terhadap pelanggaran peraturan, dan penilaian kinerja tahunan. Ketiga aktivitas operasional tersebut merupakan upaya institusi untuk memberdayakan karyawan dengan optimal sehingga mampu mencapai produktivitas yang tinggi. Menurut penelitian Hertyana (2016) bahwa penerapan absensi fingerprint sangat baik karena dapat membantu perusahaan mengontrol jam kerja pegawai secara efisien dan pegawai menanggapi baik dan menurut Fadila \& Septiana (2019) bahwa dimensi sekuritas absensi fingerprint berpengaruh positif dan penting untuk meningkatkan disiplin pegawai. Penerapan disiplin dengan memberlakukan peringatan bagi pegawai yang melanggar sesuai dengan penelitian Budirianti et al. (2020) bahwa disiplin kerja berpengaruh penting terhadap kinerja karyawan dan Oktaviannur \& Pratama (2016) bahwa disiplin yang tinggi dapat 
meningkatkan kinerja pegawai. Pentingnya penilaian kinerja juga sesuai dengan penelitian Subekti (2021) bahwa adanya penilaian kinerja pada perusahaan berpengaruh penting dan positif terhadap kepuasan pegawai dan berpengaruh positif terhadap motivasi kerja karyawan.

Berdasarkan penjelasan di atas, maka persyaratan profesional jenjang karir pegawai kelompok Staf Non-Dosen di ATS menggunakan instrumen kepemimpinan, kompetensi manajerial, dan kompetensi K3. Persyaratan operasional jenjang karir pegawai kelompok Staf Non-Dosen menggunakan instrumen kehadiran kerja, disiplin kerja, dan penilaian kinerja. Kedua persyaratan di atas menjadi dasar dalam menyusun panduan jenjang karir pegawai kelompok Staf Non-Dosen ATS.

\section{Tingkatan jenjang karir pegawai}

Tingkatan jenjang karir pegawai kelompok Staf Non-Dosen dilakukan perubahan berdasarkan persyaratan jenjang Pendidikan formalnya. Pegawai dengan jenjang Pendidikan formal Diploma III memiliki tingkatan jenjang karir 2 level dan untuk jenjang Pendidikan Sarjana memiliki tingkatan jenjang karir 3 level. Masing-masing level memiliki 4 ruang, yaitu ruang A, B, C, dan D sehingga keseluruhan terdapat delapan tingkatan untuk Diploma III dan 12 tingkatan untuk Sarjana. Untuk tingkatan pada level I adalah IA, IB, IC, dan ID. Untuk level II dan III adalah IIA, IIB, IIC, dan IID, IIIA, IIIB, IIIC, dan IIID.

\section{Instrumen pengelolaan karir pegawai}

Pengelolaan karir pegawai kelompok Staf Non-Dosen memiliki tujuan untuk mengembangkan kemampuan profesionalnya dan meningkatkan efektivitas peran operasionalnya dalam rangka mencapai tujuan institusi, baik di bidang pendidikan maupun bidang produksi. Pengembangan karir pegawai jangka panjang yang direncanakan sistematis mendorong pertumbuhan dan perkembangan profesi. (Adhikari, 2020). Pengelolaan karir pegawai kelompok Staf Non-Dosen memiliki dua instrumen yaitu unsur profesional dan operasional. Instrumen unsur profesional terdiri dari tiga kategori, yaitu 1) kompetensi keahlian teknis, 2) kompetensi keahlian manajerial dan kepemimpinan, dan 3) kompetensi keselamatan dan kesehatan kerja (K3). Instrumen unsur operasional terdiri tiga kategori, yaitu: 1) prestasi kehadiran kerja, 2) prestasi disiplin kerja, dan 3) penilaian kinerja.

\section{Kompetensi keahlian teknis bagi officer administrasi dan pengawas produksi}

Berdasarkan analisis dan pembahasan pada penelitian ini, maka kompetensi keahlian tehnis pegawai kelompok Staf Non-Dosen bagi Officer Administrasi dan Pengawas Produksi adalah seperti pada Tabel 1.

Tabel 1. Kompetensi teknis

Officer Administrasi Pengawas Produksi

\section{Melakukan perhitungan matematika dasar.}

Menggunakan aplikasi perkantoran Microsoft Office.

Membuat surat resmi yang standar perguruan tinggi dan umum.

Menggunakan Bahasa Indonesia yang benar dalam lisan dan tulisan.

Menggunakan Bahasa Inggris dengan memadai.

Menyusun deskripsi kerja pada unit kerja administrasi dan kepegawaian.

Membuat matriks alokasi sumber daya, peran, dan tanggung jawabnya pada unit kerjanya.

Menyusun standard operating procedure untuk kebutuhan operasi administrasi, kepegawaian, dan layanan umum. Mengetahui prinsip-prinsip penyusunan rencana kerja operasional.

Membuat sasaran mutu dan prinsip-prinsip kepastian mutu.

Melakukan pemecahan masalah dan proses pembuatan keputusan.

\author{
Melakukan perhitungan matematika \\ dasar. \\ Membaca Gambar Teknik dan membaca \\ Gambar Kerja. \\ Menggunakan alat ukur dan alat \\ pemeriksa dengan baik dan benar. \\ Melakukan quality control sesuai standar \\ toleransi. \\ Membuat gambar dengan alat sederhana \\ maupun dengan CAD. \\ Menggunakan mesin yang umum \\ digunakan di unit kerjanya. \\ Menganalisis kelayakan mesin yang akan \\ digunakan untuk produksi. \\ Menganalisis dan memilih material yang \\ digunakan. \\ Mampu menjelaskan tehnik kerja yang \\ benar menggunakan mesin dan peralatan.
}


Menyusun strategi dalam rangka mengoptimalkan peran dan tanggung jawab pegawai administrasi.

Menganalisis kinerja pelaksanaan sistem administrasi.

Mengetahui prinsip-prinsip etika kerja pada unit kerja administrasi dan layanan umum.

Memecahkan masalah untuk mengusulkan solusi dari berbagai solusi yang memungkinkan.

Mengatur tim untuk memecahkan masalah dan mencapai tujuan dengan kualitas standar.

Mengetahui dasar-dasar manajemen keuangan.

Mengetahui dasar-dasar manajemen sumber daya manusia.

Mmbangun semangat tim yang positif dan penanganan yang efektif kinerja tim secara keseluruhan pada unit kerjanya.

Mengetahui tentang kepemimpinan, motivasi dan prinsipprinsip manajemen.

Kemampuan dalam merencanakan dan mengorganisasi kegiatan.
Melakukan perencanaan peralatan dan material yang digunakan.

Membaca perintah kerja berbahasa Inggris.

Membuat gambar bentangan mesin dan fabrikasi.

Membuat keputusan tindakan koreksi atas pekerjaan apabila terdapat potensi penyimpangan mutu.

Melakukan komunikasi dan diskusi dengan atasan dan bawahan.

Menjelaskan kepada anggota timnya cara kerja mesin- mesin produksi.

Membuat perencanaan pembuatan mal dan alat pengarah kerja.

Menganalisis gambar yang akan dikerjakan untuk menentukan sumber daya dan biaya pokok produksi.

\section{Kompetensi keahlian manajerial dan kepemimpinan bagi officer administrasi dan pengawas produksi}

Berdasarkan analisis dan pembahasan pada penelitian ini, maka kompetensi keahlian manajerial dan kepemimpinan pegawai kelompok Staf Non-Dosen bagi Officer Administrasi dan Pengawas Produksi adalah seperti pada Tabel 2.

Tabel 2. Kompetensi manajerial dan kepemimpinan

Officer Administrasi Pengawas Produksi

Menyusun strategi pengelolaan pada organisasi administrasi perguruan tinggi.

Menggunakan kekuatan kelompok dalam bekerja.

Mengelola kemampuannya untuk melakukan kegiatan inovatif untuk mencapai sasaran mutu unit kerjanya.

Mengetahui dasar-dasar kepemimpinan dan tanggung jawab manajemen.

Melaksanakan manajemen administrasi institusi yang meliputi mengatur sumber daya tenaga administrasi, menentukan kriteria kinerja proses administrasi, dan mengomunikasikan kinerja. Menerapkan manajemen waktu dan prioritas kerja.

Monitoring dan meninjau kinerja sistem administrasi, memecahkan masalah, dan membuat keputusan.

Mengevaluasi manajemen administrasi yang meliputi sistem administrasi, kepatuhan terhadap peraturan dan persyaratan organisasi, dan capaian kinerja.

Melakukan penilaian kinerja karyawan administrasi.

Menulis dalam bahasa Indonesia dan Inggris.
Menyusun strategi pengelolaan unit kerja pada organisasi produksi.

Menjadi teladan yang baik terhadap bawahan dan teman sejawat.

Memberikan contoh kedisiplinan di dalam bekerja dan di luar tempat kerja.

Memberikan contoh bekerja dengan semangat untuk mencapai sasaran.

Membuat laporan jam kerja harian dan mingguan.

Membuat penilaian pada karyawan dengan obyektif.

Membagi pekerjaan pada karyawan sesuai kemampuan/level karyawan.

Berkomunikasi dengan baik kepada atasan, sejawat, dan bawahan.

Memberikan pengarahan pada karyawan yang melanggar kedisiplinan.

Memberikan solusi jika terjadi kesalahan pekerjaan di bengkel.

Berkoordinasi dan berkomunikasi dengan baik dengan para stakeholder.

Membuat rencana anggaran dan pembuatan proposal pengadaan peralatan.

Memberikan perintah kerja dan pengarahan dan pendampingan pada timnya. 


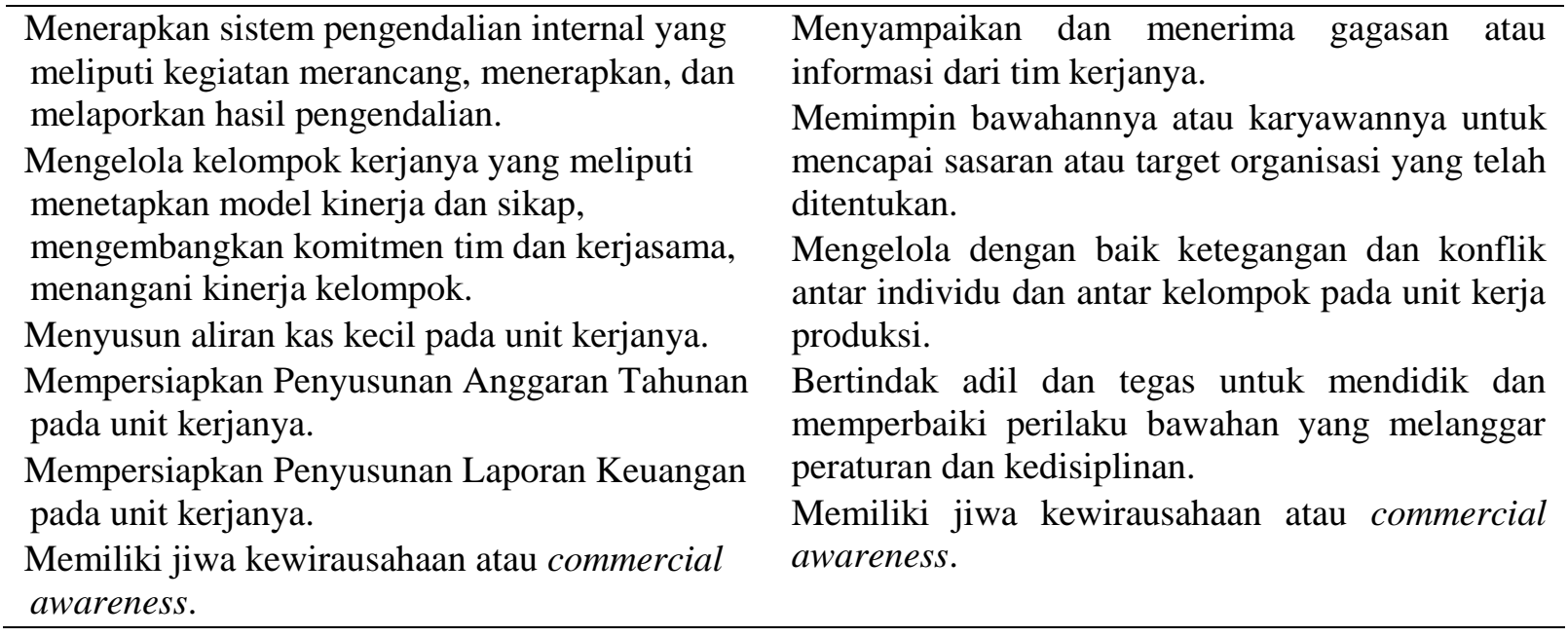

\section{Kompetensi keahlian K3 bagi officer administrasi dan pengawas produksi}

Berdasarkan analisis dan pembahasan pada penelitian ini, maka kompetensi keahlian K3 bagi pegawai kelompok Staf Non-Dosen bagi Officer Administrasi dan Pengawas Produksi adalah seperti pada Tabel 3.

Tabel 3. Kompetensi keselamatan dan kesehatan kerja, serta lingkungan

\begin{tabular}{ll}
\hline Officer Administrasi & Pengawas Produksi \\
\hline Mengetahui semua jenis alat & Melakukan pengukuran potensi bahaya di tempat kerja unit \\
pelindung diri yang standar di unit & produksi. \\
kerja administrasi. & Mengetahui semua jenis alat pelindung diri yang standar \\
Menjadi contoh penggunaan alat & pada unit produksi. \\
pelindung diri dengan benar dan tepat & Menjadi contoh penggunaan alat pelindung diri dengan benar \\
sesuai standar. & dan tepat sesuai standar. \\
Mendemonstrasikan cara penggunaan & Mendemonstrasikan cara penggunaan alat pelindung diri \\
alat pelindung diri secara standar & secara standar kepada tim kerjanya. \\
kepada tim kerjanya. & Mampu memberikan arahan untuk memotivasi anggota \\
Mampu memberikan arahan untuk & timnya untuk menggunakan alat pelindung diri dengan baik \\
memotivasi anggota timnya untuk & dan benar. \\
menggunakan alat pelindung diri & Membuat prosedur kerja standar (PKS) pada unit kerja \\
dengan benar. & produksi sesuai dengan mesin dan peralatan yang digunakan. \\
Membuat prosedur kerja standar di & Memberikan arahan kepada bawahan tentang cara \\
unit kerja administrasi. & menginterpretasikan PKS. \\
Memberikan arahan kepada bawahan & Membuat laporan pelaksanaan K3L seperti laporan toolbox \\
tentang cara menginterpretasikan & meeting dan laporan insiden. \\
prosedur kerja standar. & Membuat Job Safety Analysis bagi pekerjaan-pekerjaan baru. \\
Menyusun peralatan kantor agar & Menganalisis alat pelindung diri kebutuhan dan kelayakan \\
memenuhi standar tata letak yang baik & yang akan digunakan pada setiap pekerjaan. \\
dan aman sesuai prinsip argonomi. & Menyusun mesin dan peralatan produksi agar memenuhi \\
Melakukan penyeleksian dan memilah & standar tata letak yang baik dan aman sesuai prinsip \\
peralatan administrasi yang masih & keselamatan dan argonomi. \\
digunakan dan yang reject sesuai & Melakukan penyeleksian dan memilah peralatan produksi \\
prinsip 5S. & yang masih digunakan dan yang reject sesuai prinsip 5S. \\
\hline
\end{tabular}

Ketentuan pemenuhan kompetensi setiap tingkatan jabatan

Ketentuan-ketentuan keahlian teknis, manajerial dan kepemimpinan, dan keselamatan dan kesehatan kerja pegawai kelompok Staf Non-Dosen untuk jabatan Officer Administrasi dan Pengawas Produksi pada setiap tingkatan diukur dengan besarnya prosentase yang telah terpenuhi berdasarkan kompetensi Tabel 1, Tabel 2, dan Tabel 3. Prosentase setiap tingkatan jabatan adalah seperti Tabel 4. 
Tabel 4. Prosentase pemenuhan kompeten setiap tingkatan jabatan

\begin{tabular}{|c|c|c|c|c|}
\hline $\begin{array}{l}\text { Tingkatan } \\
\text { Jabatan }\end{array}$ & Jabatan & $\begin{array}{l}\text { Kompetensi } \\
\text { Teknis }\end{array}$ & $\begin{array}{l}\text { Kompetensi } \\
\text { Manajerial dan } \\
\text { kepemimpinan }\end{array}$ & $\begin{array}{l}\text { Kompetensi } \\
\text { Keselamatan kerja } \\
\text { dan lingkungan }\end{array}$ \\
\hline \multirow[t]{2}{*}{ IA } & Officer Administrasi & $40 \%$ & $60 \%$ & $60 \%$ \\
\hline & Pengawas Produksi & $50 \%$ & $50 \%$ & $70 \%$ \\
\hline \multirow[t]{2}{*}{ IB } & Officer Administrasi & $55 \%$ & $70 \%$ & $70 \%$ \\
\hline & Pengawas Produksi & $60 \%$ & $60 \%$ & $80 \%$ \\
\hline \multirow[t]{2}{*}{ IC } & Officer Administrasi & $65 \%$ & $75 \%$ & $80 \%$ \\
\hline & Pengawas Produksi & $70 \%$ & $70 \%$ & $90 \%$ \\
\hline \multirow[t]{2}{*}{ ID } & Officer Administrasi & $75 \%$ & $80 \%$ & $90 \%$ \\
\hline & Pengawas Produksi & $80 \%$ & $80 \%$ & $95 \%$ \\
\hline \multirow[t]{2}{*}{ IIA } & Officer Administrasi & $85 \%$ & $85 \%$ & $100 \%$ \\
\hline & Pengawas Produksi & $90 \%$ & $90 \%$ & $100 \%$ \\
\hline \multirow[t]{2}{*}{ IIB } & Officer Administrasi & $90 \%$ & $90 \%$ & $100 \%$ \\
\hline & Pengawas Produksi & $95 \%$ & $95 \%$ & $100 \%$ \\
\hline \multirow[t]{2}{*}{ IIC } & Officer Administrasi & $95 \%$ & $95 \%$ & $100 \%$ \\
\hline & Pengawas Produksi & $100 \%$ & $100 \%$ & $100 \%$ \\
\hline \multirow[t]{2}{*}{ IID } & Officer Administrasi & $95 \%$ & $100 \%$ & $100 \%$ \\
\hline & Pengawas Produksi & $100 \%$ & $100 \%$ & $100 \%$ \\
\hline
\end{tabular}

Persyaratan unsur operasional kenaikan pangkat pegawai

Pengelolaan karir fungsional pegawai kelompok Staf Non-Dosen unsur operasional bagi Officer Administrasi dan Pengawas Produksi terdiri dari tiga komponen, yaitu: 1) prestasi kehadiran kerja, 2) prestasi disiplin kerja, dan 3) penilaian kinerja pegawai. Ketiga komponen tersebut menjadi persyaratan bagi pegawai yang akan mengajukan kenaikan tingkat dan jabatan.

\section{Prestasi kehadiran kerja}

Prestasi kehadiran kerja adalah nilai yang diberikan kepada setiap pegawai kelompok Staf NonDosen untuk jabatan fungsional Officer Administrasi dan Pengawas Produksi berdasarkan keberhasilannya dalam memenuhi kehadiran tepat waktu pada awal jam kerja dengan datang tidak terlambat ke tempat kerja dan tepat waktu di akhir jam kerja dengan tidak pulang lebih awal dari ketentuan jam kerja normal. Setiap pegawai mendapatkan nilai prestasi kehadiran kerja maksimum $100 \%$ setiap bulan yang menunjukkan prestasi maksimum dalam memenuhi kehadiran kerja tanpa adanya keterlambatan waktu datang dan tanpa adanya pulang yang lebih awal sesuai rekaman data pada mesin pencatat kehadiran (finger print machine) atau pada absensi tercatat manual. Dalam hal pegawai melakukan keterlambatan waktu datang atau melakukan tindakan untuk pulang lebih awal dari ketentuan pada 22 hari kerja setiap bulan, maka nilai prestasinya akan mengalami pengurangan dari $100 \%$ sesuai dengan jumlah keterlambatannya. Keterlambatan waktu datang untuk satu kali kejadian akan mendapatkan pengurangan nilai sebesar setengah dari $1 / 22$ hari kerja atau sama dengan $2,25 \%$ dan waktu pulang yang lebih awal akan mendapatkan pengurangan nilai yang sama 2,25\% pada bulan berjalan. Keterlambatan waktu datang dan waktu pulang yang lebih awal secara bersamaan pada satu hari penuh akan mengalami pengurangan nilai satu kali $1 / 22$ hari kerja atau sama dengan $4,5 \%$. Untuk pengusulan kenaikan tingkatan jabatan dapat dilakukan setiap pegawai jika nilai prestasi kehadiran tahunan yang dihitung berdasarkan rata-rata nilai prestasi bulanan memenuhi persyaratan, yaitu 1) kenaikan tingkatan jabatan menuju IB, IC, dan ID harus memiliki nilai prestasi kehadiran kerja ratarata paling rendah adalah 98,5\% setiap tahun dan 2) kenaikan tingkatan jabatan menuju IIA, IIB, IIC, dan IID harus memiliki nilai prestasi kehadiran kerja rata-rata paling rendah adalah $99,0 \%$ setiap tahun.

\section{Prestasi disiplin kerja}

Prestasi disiplin kerja adalah nilai yang diberikan kepada setiap pegawai kelompok Staf NonDosen untuk jabatan fungsional Officer Administrasi dan Pengawas Produksi berdasarkan 
keberhasilannya dalam menerapkan peraturan kepegawaian dan prosedur keselamatan dan kesehatan kerja sehingga terhindar dari peringatan lisan maupun tertulis. Setiap pegawai mendapatkan nilai prestasi disiplin kerja maksimum 4,0 setiap tahun yang menunjukkan prestasi maksimum dalam melaksanakan disiplin kerja tanpa adanya peringatan. Dalam hal pegawai melakukan pelanggaran disiplin, maka setiap tindakan disiplin akan mendapatkan pengurangan nilai prestasi disiplin kerja sesuai bobot peringatannya. Peringatan Langkah I (Pengarahan Tertulis) yang diperoleh secara berturutturut selama 3 kali akan mendapatkan pengurangan sebesar 5\%. Peringatan Langkah II (Peringatan Tertulis I) akan mendapatkan pengurangan nilai sebesar 5\% setiap peringatan. Peringatan Langkah III (Peringatan Tertulis II) akan mendapatkan pengurangan sebesar $10 \%$ setiap peringatan. Peringatan Langkah IV (Peringatan Tertulis III) akan mendapatkan pengurangan nilai sebesar $25 \%$ setiap peringatan. Untuk pengusulan kenaikan tingkatan jabatan dapat dilakukan setiap pegawai jika nilai prestasi disiplin kerja akumulatif setiap pegawai dihitung dalam pengajuan proposal kenaikan pangkat dan golongan, yaitu: 1) kenaikan pangkat dan golongan menuju IB, IC, dan ID harus memiliki nilai prestasi disiplin kerja kuantitatif rata-rata paling rendah adalah 3,8 setiap tahun dan 2) kenaikan pangkat dan golongan menuju IIA, IIB, IIC, dan IID harus memiliki nilai prestasi disiplin kerja paling rendah adalah 3,9 setiap tahun.

\section{Penilaian kinerja pegawai}

Evaluasi kinerja pegawai kelompok Staf Non-Dosen untuk jabatan fungsional Officer Administrasi dan Pengawas Produksi bersifat individual yang dilakukan dalam satu periode tertentu yang merupakan salah satu persyaratan yang wajib dipenuhi pada setiap pengusulan kenaikan pangkat dan golongan. Penilaian kinerja pegawai dilakukan minimal satu kali dalam satu tahun yang merupakan capaiannya sesuai deskripsi tugas dan tanggung jawab atau sesuai penugasan yang diberikan oleh atasan langsung masing-masing. Nilai kinerja pegawai menggunakan nilai dengan skala antara 1 sampai dengan 5. Nilai 1 adalah Sangat Tidak Setuju atau nilai pencapaian terendah dan nilai 5 adalah Sangat Setuju atau nilai pencapaian tertinggi. Jumlah nilai kinerja minimum yang harus dicapai oleh setiap pegawai untuk dapat mengajukan kenaikan tingkatan pangkat, yaitu: 1) kenaikan pangkat dan golongan menuju IB, IC, dan ID harus memiliki nilai kinerja rata-rata 3,75 per tahun dan 2) kenaikan pangkat dan golongan menuju IIA, IIB, IIC, dan IID harus memiliki nilai kinerja rata-rata 4,0 setiap tahun.

\section{KESIMPULAN} sebagai berikut:

Berdasarkan hasil analisis dan pembahasan pada penelitian ini, maka kesimpulannya adalah

1. Pegawai kelompok Staf Non-Dosen ATS memiliki tingkatan jenjang karir yang tidak sesuai dengan tujuan dan sasaran jabatannya. Terdapat kesenjangan jika dibandingkan dengan tingkatan jenjang karir pegawai kelompok Staf Dosen. Padahal kalangan praktisi dan akademisi memiliki peran yang sama-sama penting pada institusi pendidikan vokasi ATS.

2. Untuk menjaga kinerja dan mempertahankan kepuasan pegawai kelompok Staf Non-Dosen, maka diperlukan perubahan struktur jabatan fungsional. Pegawai kelompok Staf Non-Dosen Akademi Teknik Soroako adalah pegawai manajemen lini pertama yang terdiri dari Officer Administrasi dan Pengawas Produksi. Jenjang jabatan kelompok Staf Non-Dosen untuk jenjang pendidikan Diploma III memiliki dua golongan yang masing-masing terdiri dari empat tingkatan jabatan, sehingga secara keseluruhan memiliki delapan tingkatan jabatan, yaitu IA, IB, IC, ID, IIA, IIB, IIC, dan IID.

3. Karir pegawai kelompok Staf Non-Dosen digerakkan oleh dua unsur yang juga menjadi persyaratan kenaikan pangkat, yaitu unsur profesional dan operasional. Persyaratan profesional terdiri dari: 1) kompetensi tehnis, 2) kompetensi manajerial dan kepemimpinan, dan 3) kompetensi keselamatan dan kesehatan kerja. Persyaratan operasional terdiri dari 1) prestasi kehadiran kerja, 2) prestasi disiplin kerja, dan 3) penilaian kinerja pegawai.

4. Jabatan dan pangkat serta persyaratan-persyaratan kenaikan pangkat dan jabatan pegawai kelompok staf non-dosen pada perguruan tinggi Akademi Teknik Soroako disusun dalam sebuah prosedur yang dapat digunakan sebagai acuan pengelolaan karir pegawai.

\section{SARAN}

\section{Saran Praktis:}


1. Kesenjangan pengelolaan jenjang karir pegawai antara kelompok Staf Non-Dosen sebagai praktisi dan kelompok Staf Dosen sebagai akademisi dapat dihindarkan dengan cara menambah tingkatan jenjang karir dari 2 level menjadi 3 level dan masing-masing level memiliki 4 ruang.

2. Menyusun persyaratan kenaikan jenjang karir dalam bentuk panduan sangat diharapkan oleh pegawai Officer Administrasi dan Pengawas Produksi.

3. Pengembangan kompetensi pegawai berpatokan pada persyaratan unsur profesional dan unsur operasional akan sangat membantu perkembangan karir pegawai dan meningkatkan kinerjanya.

\section{Saran Teoritis:}

1. Penelitian ini masih sangat kurang dalam teknik pengambilan dan analisis data terutama tentang perbedaan antara jenjang karir Staf Non-Dosen dan Staf Dosen sehingga dapat diperbaiki dengan menggunakan teori-teori yang lebih sesuai dan terbarukan.

2. Penelitian selanjutnya dapat menggunakan metode pengumpulan data melalui kuisioner terhadap pegawai dan manajemen dan analisis data menggunakan bantuan aplikasi Statistical Package for the Social Science (SPSS).

\section{REFERENSI}

Adhikari, H. P. (2020). Employee Development and Career System for Enhancing Professionalism in the Public Sector of Nepal. South Asian Journal of Policy and Governance (SJPG), 44(2), 88101.

Aguinis, H. (2013). Performance Management (3rd ed.). Pearson Education, Inc.

Armstrong, M. (2009). Armstrong's Handbook of Performance Management: An Evidence-based Quide to Delivering High Performance (4th ed.). Kogan Page Limited.

Bhardwaj, A., \& Punia, B. K. (2013). Managerial Competencies and Their Influence on Managerial Performance: A Literature Review Introduction. International Journal of Advanced Research InManagement and Social Sciences, 2(5), 70-84.

Brown, S. D., \& Lent, R. W. (2013). Career Development and Counseling Putting Theory and Research to Work (2nd ed.). John Wiley \& Sons, Inc.

Budiadnyana, G. N., Sasono, I., Novitasari, D., Suroso, \& Sutardi, D. (2021). Peran Mediasi Knowledge Management di Industri Manufaktur: Antara Kepemimpinan dan Inovasi. Jurnal Manajemen dan Akuntansi, 16(1), 141-156.

Budirianti, B., Agusdin, \& Surat. (2020). The Influence of Work Discipline, Motivation, Job Satisfaction and the Work Environment on the Performance of Contract Employees. International Journal of Multicultural and Multireligious Understanding, 7(11), 174-184. https://doi.org/http://dx.doi.org/10.18415/ijmmu.v7i11.2174

Butali, P., \& Njoroge, D. (2018). Effect of Performance Appraisal on Organizational Performance. International Journal of Science and Research, 7(9), 685-690. https://doi.org/10.21275/ART2019724

Fadila, R., \& Septiana, M. (2019). Pengaruh Penerapan Sistem Absensi Finger Print Terhadap Disiplin Pegawai pada Markas Komando Direktorat Pengamanan Badan Pengusahaan Batam. Journal of Business Administration, 3(1), 53-61.

Garnida, D. (2017). Pengaruh Pendidikan, Pengalaman Kerja dan Prestasi Kerja Terhadap Pengembangan Karir Pegawai di Dinas Pekerjaan Umum Kabupaten Kutai Timur. Jurnal Pemerintahan Integratif, 5(4), 626-635.

Hanum, N., Munandar, J. M., \& Purwono, J. (2020). The Influence of Competence and Knowledge Management on Performance. Journal of Applied Management (JAM), 8(2), 252-260. https://doi.org/http://dx.doi.org/10

Harnawan, S., \& Hakim, L. (2020). Pengaruh Kompetensi, Program Keselamatan dan Kesehatan Kerja Terhadap Produktivitas Kerja Karyawan Divisi Gedung Pada PT Hutama Karya (Persero). Jurnal Ilmu Ekonomi dan Akuntansi, 1(2), 168-178. https://doi.org/https://doi.org/10.3701/ileka.v1i2

Hedge, J. W., \& Rineer, J. R. (2017). Improving Career Development Opportunities Through Rigorous Career Pathways Research. RTI Press Publication. https://doi.org/10.3768/ rtipress.2017.op.0037.1703

Hertyana, H. (2016). Pengaruh Sistem Absensi Fingerprint Terhadap Kinerja Karyawan Pada PT. Deltacomsel Indonesia. Jurnal Teknik Komputer AMIK BSA, 2(2), 42-48. 
Ismail, F., \& Sudarmadi, D. (2019). Pengaruh Sistem Informasi Akuntansi dan Pengendalian Internal Terhadap Kinerja Karyawan PT Beton Elemen Persada. Jurnal Akuntansi, Audit dan Sistem Informasi Akuntansi, 3(1), 1-13.

Junaedi, Nuraeni, \& Halimah. (2019). Pengaruh Kompetensi Manajerial Dan Supervisi Kepala Sekolah Terhadap Kinerja Guru Ra Pc Weru Kabupaten Cirebon. Islamic Education Journal, 1(2), 234248.

Karyono. (2021). Gaya Kepemimpinan, Lingkungan Kerja, dan Kinerja Karyawan pada Departemen Welding PT Paramount Bed Indonesia. Manajemen dan Akuntansi, 16(1), 64-75.

Kathuria, R., Partovi, F., \& Greenhouse, J. (2010). Leadership Practices, Competitive Priorities, and Manufacturing Group Performance. International Journal of Operation and Production Management, 30(10), 1080-1104.

Khotimah, C. (2018). Pengaruh Kompetensi dan K3 (Keselamatan dan Kesehatan Kerja) Terhadap Kinerja Karyawan Pada PT. Lotus Indah Textile Industries Bagian Winding di Nganjuk. Jurnal Ilmu Manajemen, 2(3), 118-125.

Oktaviannur, M., \& Pratama, A. (2016). Influence of Work Motivation and Work Discipline on The Performance of Employees in Regional General Hospital in the District Demang Sepulau Raya Central Lampung. The Third International Conference on Law, Business and Government, 5157.

Parta, I. W. G. I., \& Mahayasa, I. G. A. (2021). Pengaruh Keterampilan Kerja, Team Work, dan Motivasi terhadap Kinerja Karyawan Bagian Produksi pada Art Shop Cahaya Silver di Celuk, Gianyar. Jurnal Manajemen, Kewirausahaan, dan Pariwisata, 1(1), 65-76. https://doi.org/10.32795/widyaamrita.v1i1.1147

Pio, R. J. (2017). Perencanaan dan Pengembangan Karir. Seminar Nasional TIK dan Ilmu Sosial, 7(2), 207-215.

Rivai, V., \& Sagala, E. J. (2009). Manajemen Sumber Daya Manusia untuk Perusahaan (Jakarta). Rajawali Pers.

Sharma, S., \& Taneja, M. (2018). The Effect of Training on Employee Performance. International Journal of Recent Technology and Engineering, 7(4), 6-13. https://doi.org/10.36555/almana.v4i3.1477

Subekti, A. (2021). The Influence of Performance Appraisal System Towards Job Satisfaction, Motivation, As Well As Employee Performance. International Journal of Economics, Business, and Accounting Research (IJEBAR), 5(2), 104-114. https://jurnal.stieaas.ac.id/index.php/IJEBAR

Tan, F. (2008). Linking Career Development Practices to Turnover Intention: The Mediator of Perceived Organization Support. Journal of Business and Public Affairs, 2(1), 1-20.

Tombokan, P. E., Kindangen, P., \& Dotulong, L. (2017). Pengaruh Pendidikan dan Kinerja Terhadap Karir Pegawai pada Badan Keuangan dan Asset Daerah Kabupaten Minahasa Utara. Jurnal Riset Ekonomi, Manajemen, Bisnis dan Akuntansi, 5(2), 2676-2684.

Wahyuni, N., Suyadi, B., \& Hartanto, W. (2018). Pengaruh Keselamatan dan Kesehatan Kerja (K3) Terhadap Produktivitas Kerja Karyawan pada PT. Kutai Timber Indonesia. Jurnal Pendidikan Ekonomi, 12(1), 99-104. https://doi.org/: 10.19184/jpe.v12i1.7593

Wirda, F., Azra, T., \& Herizon. (2016). The Influence of Managerial Competency and External Environment on the Competitive Advantage of a Creative Industries in West Sumatra. Jurnal Sosial dan Pembangunan, 32(1), 126-138.

Wulandari, A. (2017). Influence of Education and Work Experience on Work Motivation and Job Performance at Branch Office of BANK J Trust Bank Surabaya. International Journal of Society Development and Engagement, 1(1), 1-20. 